\title{
INNOVATIVE METHODS OF TEACHING ENGLISH IN CYBER SOCIETY
}

\author{
Oksana Babelyuk \\ Prof., DSc, Lviv State University of Life Safety, Ukraine \\ e-mail: babelyuko@gmail.com,orcid.org/0000-0003-4837-1225 \\ Maria Malanyuk \\ Senior Lector, Lviv State University of Life Safety, Ukraine \\ e-mail: maria.malanyuk@gmail.com, orcid.org/0000-0002-1290-0407 \\ Iwona Wiraszka \\ MA, Polonia University in Częstochowa, Poland \\ e-mail: activefactory@wp.pl, orcid.org/0000-0002-2207-8242

\section{Andrii Galaidin} \\ Ph.D. student, Polonia University in Czestochowa, Interdisciplinary Faculty, Poland \\ e-mail: a.galaidin@ap.edu.pl,orcid.org/0000-0002-5236-1495
}

\section{Summary}

This paper discusses the innovative and interesting methods of teaching English. There are variety of teaching methods ranging from traditional to modern. Everyone has their own perspective and conclusions about teaching English as a foreign language. It is proved that whatever the teaching methodology, it must be centered on the learner as his mind is never static; it is constantly growing and changing. The practical part of this article aims to show the awareness of teachers regarding the innovative technologies and methodologies as well as to locate students' reactions to the implementations of these methodologies.

Keywords: teaching methodology, innovation, technology, second language learning.

DOI: https://doi.org/10.23856/4402

\section{Introduction}

Nowadays, due to the continuous development of educational technologies and teaching methodologies, teachers are facing a great challenge. They must not only stay up with the emerging teaching methodologies but also with new educational technologies that have become an integral part of the educational process.

This article discusses on innovative teaching approaches and educational tools. It also aims to show the awareness of teachers regarding these technologies and methodologies.

The vast pedagogical group is only now beginning to comprehend the educational technologies' position in the modern educational system. It's because of the rapid growth of stance/ remote education, which was made more relevant by the COVID-19 lockdown. It became clear that it was not only a good example of a foreign educational experience but that it was also our own (Babeluyk, 2020; 2021).

Teachers of English as a second language employ a variety of techniques, practices, and tactics based on methods derived from approaches or language learning theories influenced by learning theories. (Babelyuk, 2020; Babelyuk, 2021; Brown, 2001; Freeman, 2008; Harmer, 2001; Nunan, 1999; Richards \& Rodgers, 2002; Nunan, 1999; Richards \& Rodgers, 2002). What they're doing in class is a reflection of a method, the application of a specific principle, and "the 
formulation of a constructive approach imposed on the learning process" (Widdowson, 2003, p. 19). However, many English teachers use methodological techniques without recognizing the theoretical connections. For them, tangible changes and outcomes are valid and necessary; they must observe student learning and monitor progress. Learning is, in reality, an overall corollary of education, and what matters most to language teachers is the evolution of learning, which can only be evaluated by meaningful learning outcomes.

On the other hand, there are English teachers who actively use the methods and concepts of the methodologies they advocate (Malanyuk, 2019). They see a theoretical connection between learning theories, techniques, and processes, as well as learning. Naturally, deciding which techniques and strategies are best and/or most suitable for their own teaching situations is extremely difficult (Babeluyk, 2020; Harmer, 2001, p. 96). When they choose from a variety of strategies or techniques, they are often referred to as eclectic. "Eclecticism is not the same as random expediency, a spontaneous reaction to immediate circumstances, but rather a matter of selecting from a variety of options," says the author (Widdowson, 2003, p. 19). As a consequence, English language teachers must be acquainted with these methods or approaches to accurately use them.

For many years, Communicative Language Teaching was regarded as a paradigm shift in language learning. "Communicative Language Teaching has evolved into a generic "umbrella" term for educational sequences aimed at improving students' ability to communicate" (Harmer, 2001, p. 86). There are still some language teachers who regard this methodology as the final method of language instruction. Indeed, Communicative Language Teaching was a watershed moment in the history of language learning. Previously accepted facts and practices in language learning have begun to be questioned. The grammar teaching method became outdated; activities and tasks were all communicative in nature, and classrooms and materials were redesigned to provide learners with additional communicative options and opportunities. Language teachers became the method's primary adherents.

Following Communicative Language Teaching, significant events occurred that altered the latitude and characteristics of learning in general: the integration of computer technologies into education, the impact of constructivist learning theory, and the widespread use of the internet in all facets of human life. Similarly, "Language teaching methods have shifted their emphasis away from the personal in language learning" (Huttner, 2012), and learner-centeredness has become a primary factor in designing, planning, and implementing educational practices. All of these changes have resulted in the introduction of several innovative language learning methodologies. These methodologies incorporated or adhered to a variety of language learning theories, approaches, and practices.

The term "methodologies of language learning" refers to "pedagogical practices in general, including their theoretical underpinnings and related research." Whatever considerations go into determining 'how to teach,' they are methodological in nature" (Brown, 2001, p. 15). Similarly, the term "language learning methodology" is used in this study to refer to pedagogical practices that are based on any particular language learning theory, approach, or method; for example, Audio-Lingual Methodology is used rather than Audio-Lingual Method. Each of these methodologies claims that it improves the effectiveness and appeal of language learning.

The two central components of the language learning process are language learners and teachers. Almost everything in language learning methodologies is structured in relation to learners and teachers (Huttner, 2012). Learners and teachers will find objectives, principles, and techniques. The roles of learners and teachers are theoretically defined in accordance with the methodology of language learning methodologies. 
Teachers' primary role is unquestionably to internalize the rationales for these language learning methodologies' practices. Knowledge of these methodologies "provides an additional avenue for professional growth... not through the introduction of novel principles, but rather through the application of novel techniques" (Freeman, 2008, $p$. 8). Teachers should be developing theory and theorizing their practice, not simply applying theory to practice (Huttner, 2012). They must understand the methodologies' historical context, their relationship to approaches and learning theories, their primary objectives and principles, as well as their applications and practices. They can only be successful in facilitating learning, constructing theory, and theorizing their practice if they are aware of these. As a result, language teachers should look beyond Communicative Language Teaching and incorporate innovative language learning methodologies that already exist.

\section{Literature review}

Numerous innovative language learning methodologies are in use today. All of these initiatives aim to improve the effectiveness and appeal of language learning. English language teachers should be familiar with these methodologies in order to make informed decisions about which to implement in their classrooms.

The Communicative Language Learning Methodology organizes the entire process of language learning around communication, which is widely regarded as the primary goal of any language. Language learners must understand that language is used for communication and is not out of their control. The learning processes and learning spaces in this methodology place importance on communication, negotiating and conveying the meaning, and interpreting. (Babelyuk 2017; Babelyuk, 2020; Davies \& Pearse, 2000; Freeman, 2008; Littlewood, 1981; Nunan, 1999; Littlewood, 1981; Nunan, 1981).

The blended/hybrid language learning methodology combines face-to-face lessons with online learning spaces. Blended learning is the deliberate blending of face-to-face and online learning experiences. Sharma and Barrett state that this methodology "integrates a face-to-face classroom component with appropriate use of technology, such as the internet, CD-ROMs, and interactive whiteboards" $(2007, p$. 7). "The fundamental principle is that oral and written communication should be optimally integrated so that the strengths of each are combined to create a unique learning experience..." (Vaughan \& Garrison, 2007, p. 5).

In Cooporative/Caborative Methodology learners cooperate to improve their language skills. Language learners benefit from one another and their experiences collaborating in groups. Teachers guide students on how to use collaborative and social skills effectively when interacting with one another (Freeman, 2008). In general education, the term "competency-based language learning methodology" refers to all teaching and learning approaches that structure their learning processes around competencies (Kamphorst, Hofman, Jansen \& Terlouw, 2013). The methodology focuses on critical language learning competencies and aims to improve learners' cognitive and behavioral abilities.

The Connectivist Language Learning Methodology asserts that it is the most recent paradigm in education. According to connectivist theory, "learning can take place outside of ourselves (in an organization or a database), is centered on connecting specialized information sets, and the connections that enable us to learn more are more important than our current state of knowledge" (Siemens, 2005, p. 8). Language students create networks and nodes of learning instances that are all connected via knowledge pipes. Through the establishment and use of these networks, learning occurs and develops. Language teachers should assist in the 
establishment of learning networks and nodes. According to constructivist language learning theory, individuals "construct their own version of reality," and thus multiple contrasting modes of knowing and describing are equally legitimate (Brown, 2000, p. 11). Knowledge is not an abstract isolated phenomenon; it is constructed by individuals drawing on their prior knowledge and interacting with new information. Because things become known or learned through prior knowledge and experience, learners should be presented with numerous opportunities to construct knowledge in their own unique way. Individuals engaged in related activities discover the optimal method of learning or knowledge construction.

The method of content-based language learning integrates content and language. While interacting with the content, learners acquire language skills. In theory, Content-based Language Learning / Content-language Integrated Language Learning Methodology entails the interweaving of content and language "without an implicit preference for either" (Coyle 2007, 545). "Through planned, purposeful, and academically based activities that develop students' linguistic and critical thinking abilities and engage them in meaningful and authentic language processing, it fosters a functional language learning environment that goes beyond simply presenting information in a second language" (Kasper, 2000, p. 3).

The Differentiated Language Learning Methodology is designed for language learners with diverse intellectual and language abilities. Learners do not have the same knowledge, skills, or potentials. Teachers acknowledge and build on the premise that students differ significantly in important ways (Tomlinson, 1999). That is, in fact, true in almost every language class, indicating the importance of reaching out to all students in order to ensure equal and fair participation in learning. Language teachers can differentiate materials, the pace of the lesson, and assessment throughout the language learning process using this methodology.

In Learning by Teaching Methodology students are guided to teach parts of the lesson or even the whole lesson in to learn (Gartner, 1971). The learners practice the language in a variety of ways while preparing to teach the content and while delivering the lesson. They devote significant time to preparation and instruction, during which they practice their language skills. During the preparation, organization, and delivery of learning, teachers guide learners on the content and skills necessary to perform the necessary tasks.

According to Lewis (1993), "Lexical Language Learning Methodology is based on the idea that an important aspect of language acquisition is the ability to comprehend and produce lexical phrases as unanalyzed wholes, or'chunks,' and that these chunks serve as the raw data from which learners perceive patterns of language traditionally considered to be grammar" (Lewis, 1993, p. 95). Throughout the learning process, language learners are exposed to more lexis-oriented materials and tasks.

The Multiple Intelligences Oriented Language Learning Methodology places a premium on the learners' multiple intelligences. When language teachers plan and deliver language lessons, they take into account their students' diverse intelligence. The methodology is largely based on the theory of multiple intelligences, which is defined as "a pluralistic view of the mind that recognizes numerous distinct and distinct facets of cognition and acknowledges that individuals have varying cognitive strengths and cognitive styles" (Gardner, 1993). Multiple intelligences is a learner-centered philosophy that recognizes and develops the multiple dimensions of human intelligence (Richards \& Rodgers, 2002).

Language learners should be actively involved in the process of language learning, according to the Participatory Language Learning Methodology. All materials should have meaning for students and be integrated into their lives. They must make connections between language learning content and their life experiences, participate in authentic tasks, and take 
responsibility for the events that occur around them. "What matters is not the content of subject-matter texts, but rather content that is based on student-identified issues" (Freeman, 2008, p. 150). This methodology encourages students to bring real-world situations into the classroom or to apply the lesson's content outside of class.

The Problem-based Language Learning Methodology asserts that people learn when they encounter problems and engage in the problem-solving process. Language learners, according to the methodology, concentrate on problem-solving and practice while simultaneously improving their language abilities. Students acquire content, strategies, and self-directed learning skills through collaborative problem solving, reflection on their experiences, and self-directed inquiry (Hmelo-Silver, Duncan \& Chinn, 2006, p. 100). Language learners are assigned projects structured around themes, tasks, or problems to complete. Throughout the project's completion, learners collaborate with one another, with their teachers, and with all other stakeholders. "Frequently, projects emerge from an authentic context to address contentious or significant social issues and unfold in unexpected ways (Markham, Larmer \& Ravitz, 2003, p. ix).

Reflective Language Learning Methodology encourages learners to reflect on their learning experiences, to comprehend the process of learning and their intellectual interaction through an in-depth examination of their learning experiences. "An emphasis on the learner's reflective practice enables autonomous exploration of real-world issues and places a premium on professional knowledge" (Ru, Font \& Cebrin, 2013). According to Smith and Trede (2013), reflective learning teaches students how to manage risks with autonomy, creativity, and professionalism.

The Styles and Strategies-based Language Learning Methodology states that learners should be presented with effective strategies for practicing or improving their language abilities and potentials. The learners should attempt to determine the most effective strategies that work best for their unique learning experience. The methodology aims to assist learners in identifying available strategies, comprehending how to structure and use them effectively, and adapting them to new contexts based on their preferred learning style (Cohen, 2011).

Language learners are presented with well-structured tasks as the basic element of their learning in the Task-based Language Learning Methodology. In other words, rather than focusing on language structure, students are assigned a task or a problem to solve (Harmer, 2001). "Rather than an ordered list of linguistic items, the starting point is a collection of tasks" (Nunan, 1999, p. 24). Additionally, due to its connections to Communicative Language Learning methodology and support from second language acquisition theorists, task-based learning has garnered significant attention in applied linguistics (Richards and Rodgers 2002).

Web-based Language Learning Methodology makes language learning more appealing to anyone with an internet connection by utilizing Web technologies. It is a method of language learning that makes use of the Web and makes use of Web-based materials, resources, applications, and tools (Son, 2007). According to the Whole Language Learning Methodology, students study the language as a system of meaning in order to be able to use all of the language's skills and elements to construct knowledge and meaning. The concept of language's "wholeness" here implies that language is not the sum of its various dissectable and discrete components (Brown, 2001). Additionally, learners should view language learning as a system of social practices, rather than as the study of isolated semantic, syntax, and pragmatic rules. 


\section{Methods}

This is a descriptive study aimed at determining English language teachers' awareness of innovative language learning methodologies and investigating their utilisation. The survey method was used to collect data from participants who were chosen at random. The survey method, which typically takes the form of a questionnaire, focuses on a group's attitudes, opinions, and/or characteristics and is very effective at gathering large amounts of information in a relatively short period of time.

To collect data, English language teachers were given a questionnaire with fourteen questions designed to elicit their opinions on the awareness and use of innovative language methodologies and technologies. Descriptive statistics were used for data analysis to describe different pieces of information and was the sole aim of this research. The collected data were analysed with IBM SPSS 20 statistical software to determine the frequencies and percentages of research-related questions.

\section{Participants}

The participants of the study were 100 English language teachers from schools both public and private in Poland. 34 teachers were between 35 and 43, 22 between 28 and 34, 21 teachers between 21 and 27, and 22 teachers were over 40 years old. Concerning their voluntary contribution, participants were fully informed about the confidentiality and anonymity of their participation in the research on the questionnaires administered.

\section{Findings}

Almost all of the participants were familiar with Communicative Language Learning Methodology. This is because CLLM receives the most time in nearly all English language teacher training programmes' curricula. Prospective English language teachers learn about the technique in-depth and see communicative language activities in action in the classroom. More than a half of the participants were aware of Task-based-based, Project-based, Lexical, Learning by teaching methodologies, as evidenced by the results. Learning through Participatory, Differentiated, reflective, Connectivist language methodology were only known by less than $20 \%$ of the participants. Overall, it seems that English language teachers are less informed of the most up-to-date methodologies, which they are needed to know and use more in their English language classrooms, according to the findings.

When asked if they wanted to learn/study various novel language learning methodologies, as shown in chart 5 participants selected a variety of them. Learning through Content-based, Blended, learning by teaching, project-based, Task based oriented language learning methodologies were the methodologies that they chose to learn/study more than $20 \%$ of the time. But the far most popular were Communicative and Grammar translation methods, which might be quite surprising as most of the participants claimed that they are familiar with these methods. The majority of participants showed a strong desire to learn new language learning methodologies. It is important that English language teachers are willing to learn more about novel methodologies and put them into practice. They are eager to put these new conditions of the English language into practice. They have no hesitation about changing their learning styles and strategies, demonstrating their passion for the subject. 
Teachers studied most new language methodologies in universities. Academic institutions, of course, serve as the basis for teacher education and professional instruction in the teaching and learning of the English language. Teachers who responded said they used the internet as a secondary source to learn about and research innovative language learning methodologies. Nowadays, the internet is the only source of instant knowledge and information. Teachers should be guided to reputable websites in order to obtain accurate and up-to-date information on language learning methodologies. Via classes, in-service instruction, workshops, and books/ articles, only a small number of participants learn/study creative language learning methodologies. This demonstrates the need for such activities to be organised for in-service language teachers. Via academic means, English language teachers need to be taught about new methodologies.

Participants employ language learning methodologies in the following ways: more than half of them (57\%) admitted to using methodologies techniques. This shows that when English language teachers are aware of the methodologies, they implement them. It also demonstrates the willingness of English language teachers to try out new strategies. Around 30\% of the participants said they used methodologies to structure practices and/or assignments, content design and usage (33\%), learner roles (26\%), and classroom procedures (36\%). It's clear that English language teachers are trained and ready to make effective methodological changes and modifications in their language classrooms once again. They are willing to adapt in order to improve language learning.

When asked how students reacted to new language learning methodologies, the majority of participants said they were positive (percent 82,6). The best judges of successful learning are the students. They are aware of what is beneficial, constructive, and important in their education.

The majority of the English language teachers who used innovative language learning methods considered them to be successful ( 77 percent). In terms of potential implementation, more than $77 \%$ of the participants reported that they plan to use more innovative language learning methodologies in the future. This demonstrates that English language teachers are open to innovative and successful language learning applications once again.

Regarding the usage of new educational technology, nearly $90 \%$ of participants claimed they use it. This proves again that the teachers want to follow the innovation. Among all educational technologies' films and videos were used the most often (82\%). Also very popular were apps $52 \%$, online worksheets $51 \%$, and online quizzes $55 \%$. This proves that the teachers willingly take advantage of technology

The biggest barrier which stops teachers to utilize educational technology turned out to be the lack of training $37 \%$ and lack of infrastructure $30 \%$ following by lack of syllabus $21 \%$ and consultation $15 \%$. This demonstrates the need for additional training for teachers and also the need to properly equipped schools with advanced educational tools.

\section{Conclusion}

Various language learning methodologies were introduced and practiced in language learning after Communicative Language Learning Methodology. Several of these approaches have been deemed to be highly effective and competitive. In their classes, more English language teachers are beginning to use these creative language learning methodologies. Teachers must first become familiar with these methodologies before deciding whether or not to implement them in their language classrooms. To be more effective, they must recognize the connections between language learning theories and methodologies. The aim of this study was to 
see if English language teachers were aware of creative language learning methodologies and how they were implemented. Several conclusions were taken from the results review in order to address the study's research questions.

Almost all English language teachers were familiar with the Communicative Language Learning Methodology, but few were familiar with the other language learning methodologies. The results showed that fewer than half of the teachers were familiar with the other language learning methodologies. More than $25 \%$ of teachers were unaware of fifteen of these methodologies. Less than $10 \%$ of people knew about four language learning methodologies: Learning through Teaching, Competency-based, Differentiated, and Connectivist. In general, we can deduce that English language teachers were not well-versed in innovative language learning techniques.

Teachers of English have shown a strong desire to learn and research these methodologies. The results show that they were eager to learn/study these methodologies and incorporate them into their teaching. They were aware of recent educational developments and recognized the need to develop their clinical practice. More than half of them wanted to learn/study Language Learning through Teaching, Multiple Intelligence Oriented, Web-based methodologies.

The results revealed that during their undergraduate studies, English language teachers were exposed to innovative language learning methodologies. Then they learned/studied these methodologies using the internet. The findings show that English language teachers did not learn or research innovative language learning methodologies through in-service training, courses or seminars.

English language teachers who took part in the research said they used innovative language learning methods in their classrooms. They also mentioned that they applied the concepts of these methodologies to classroom procedures, activity and task preparation, content design and adaptation, and learning assessment. They also claimed that the concepts helped them describe or classify their positions as educators. They understood their students and managed the classroom using the principles of innovative language learning methodologies.

The use of creative language learning methodologies by English language teachers was found to be successful, as evidenced by the analysis of the findings. They also reported that the implementation of these methodologies received positive feedback from their students. Teachers plan to use more of the creative language learning methodologies in the future, according to the findings.

To be more successful, English language teachers must keep up with new developments in language learning. Fortunately, teachers, administrators, and parents now have more tools and resources to guide and direct student learning. The main educational consequence of the current research, however, is that the majority of language teachers are unaware of the advanced language methodologies used in the field. They don't understand how they can use advanced technology in their classrooms by implementing these methodologies. According to the findings, the majority of English language teachers recognized the motivational benefits of using creative language methodologies. They noticed that by using creative methodologies, their students became much more collaborative, involved, and efficient, and their language learning classroom activities became more current and successful. As a result, English language teachers must become acquainted with cutting-edge language learning methodologies as soon as possible. Another educational takeaway from the study is that English language teachers are able to refresh and develop their analytical skills in English language learning. As a result, it is important that in-service English language teachers receive training on new methodologies. Language schools, research institutions, and English language organizations can work together to provide English language teachers with opportunities to learn about language learning methodologies. 
More classes, workshops, and in-service training programmes for pre-service and in-service teachers should be made available.

The fact that language teachers use the internet to learn about new language methodologies is another significant pedagogical consequence of the research. For English language teachers, the internet has become the most open-source of knowledge, content, and materials. Then it's critical that English language teachers are led to trustworthy, credible, and meticulously constructed websites by experts in the sector. These websites may also help English language learners with their language learning. The study's conclusion is that language learners are enthusiastic about the adoption of advanced language learning methodologies. When students are inspired and see progress in their learning, they are optimistic. If they do not profit from language learning activities, they are extremely important. They place a high emphasis on successful teaching, as well as practical and functional learning. For more efficient language learning, language learners should be introduced to innovative language learning methodologies as soon as possible.

\section{References}

Babelyuk, O. (2017). Culture Strategy in Translating Postmodern Literary Text. Periodyk Naukowy Akademii Polonijnej w Czesstochowie, 22(3). DOI: 10.23856/2202. [in English].

Babelyuk O., Koliasa O., Kushlyk O, Smaglii V. (2020). Using Distance EdTech for Remote Foreign Language Teaching During the COVID-19 Lockdown in Ukraine. Arab World English Journal (AWEJ) Special Issue on the English Language in Ukrainian Context, November 2020, Available at SSRN: https://ssrn.com/abstract=3735588 or http://dx.doi.org/10.2139/ ssrn.3735588

Babelyuk, O., Koliasa, O., Lopushanskyy, V., Smaglii, V., Yukhymets,S. (2021). Psychological Difficulties during the Covid Lockdown: Video in Blended Digital Teaching Language, Literature, and Culture.Arab World English Journal (AWEJ) Special Issue on Covid 19 Challenges (1) p. 172-182. DOI: https://dx.doi.org/10.24093/awej/covid.13

Brown, H. (2001). Teaching by principles : an interactive approach to language pedagogy. White Plains, NY: Longman. Brown, J. (1988). Understanding research in second language learning : a teacher's guide to statistics and research design. Cambridge England New York: Cambridge University Press.

Carter, R and D. Nunan (2001). (Ed). Teaching English to speakers of other languages.

Cambridge: Cambridge University Press. Cohen, A. (2011). Strategies in learning and using a second language. Harlow, England New York: Pearson/Longman.

Coyle, D. 2007. "Content and Language Integrated Learning: Towards a Connected

Garrison, R. D. \& Vaughan, N. D. (2007). Blended learning in higher education: Framework, principles, and guidelines. San Francisco: Jossey-Bass.

Gartner, A., Kohler, M. \& Riessman, F. (1971). Children teach children; learning by teaching. New York:

Harper \& Row. Harmer, J. (2001). The practice of English language teaching. Essex, England: Longman.

Hmelo-Silver, C.E., Duncan, R.G. \& Chinn, C.A. (2006). "Scaffolding and Achievement in Problem-Based and Inquiry Learning: A Response to Kirschner, Sweller, and Clark (2006)". Educational Psychologist. 42 (2), p. 99-107.

Huttner, J. (2012). Theory and practice in EFL teacher education: bridging the gap. Bristol, UK Tonawanda, NY: Multilingual Matters. 
Kamphorst, J.C., Hofman, W.H.A., Jansen, E.P.W.A. \& Terlouw, C. (2013) The relationship between perceived competence and earned credits in competence based higher education. Assessment \& Evaluation in Higher Education. 38(6), 646-661.

Kasper, L. (2000). Content-based college ESL instruction. Mahwah, N.J: Lawrence Erlbaum Associates.

Lewis, M. (1993). The lexical approach: The state of ELT and the way forward. Hove, England: Language Teaching Publications.

Littlewood, W. (1981). Communicative Language Teaching. Cambridge: Cambridge University Press.

Malanuyk, M. (2019). Intersemiotic Translation as a Method of Teaching English to Mentally Handicapped Students. Periodyk Naukowy Akademii Polonijnej w Częstochowie, 35 (4). DOI: http://dx.doi.org/10.23856/3511 [in English].

Markham, T., Larmer, J. \& Ravitz, J. (2003). Project based learning handbook : a guide to standards-focused project based learning for middle and high school teachers. Novato, Calif: Buck Institute for Education. Nunan, D. (1999). Second language teaching \& learning. Boston, Mass: Heinle \& Heinle Publishers.

Richards, J.C. and T. Rodgers (2002). Approaches and methods in language Teaching: a description and analysis. New York: Cambridge University Press.

Ru, J., Font, A. \& Cebrin, G. (2013) Towards high-quality reflective learning amongst law undergraduate students: analysing students' reflective journals during a problem-based learning course, Quality in Higher Education, 19:2, p. 191-209.

Seliger, H. \& Shohamy, E. (1989). Second language research methods. Oxford: Oxford University Press. Sharma, P. \& Barrett, B. (2007). Blended learning : using technology in and beyond the language classroom. Oxford: Macmillan. Siemens, G. (2005). Connectivism: A learning theory for the digital age. International Journal of Instructional Technology and Distance Learning. 2(1), 3-10.

Smith, M. \& Trede, F. (2013) Reflective practice in the transition phase from university student to novice graduate: implications for teaching reflective practice. Higher Education Research \& Development. 32(4), p. 632-645.

Son, J.-B. (2007). Learner experiences in Web-based language learning. Computer Assisted Language Learning. 20(1), p. 21-36.

Stevick, E. W. (1990) Humanism in Language Learning, Oxford: Oxford University Press.

Tomlinson, C. (1999). The differentiated classroom: responding to the needs of all learners. Alexandria, Va: Association for Supervision and Curriculum Development Tosey, P. \& Mathison, J., (2006) "Introducing Neuro-Linguistic Programming Centre for Management Learning \& Development, School of Management, University of Surrey.

Widdowson, H. (2003). Defining issues in English language teaching. Oxford: Oxford University Press. 